\title{
PENGARUH SIFAT MACHIAVELLIAN, LOCUS OF CONTROLL, DAN INDEPENDENSI TERHADAP PERILAKU ETIS AUDITOR (Studi Empiris Pada Kantor Akuntan Publik Di Yogyakarta)

\author{
Oleh,
} \\ Dra. Reni Yendrawati, M.Si (Dosen FE UII, Yogyakarta) \\ Witono, SE (Alumnus FE UIl, Yogyakarta)

\begin{tabular}{|c|c}
\hline ABSTRAK & \\
\hline
\end{tabular}

Penelitian ini dilakukan untuk memperoleh pemahaman tentang bagaimana pengaruh sifat machiavellian, locus of control, dan independensi ' terhadap perilaku etis auditor. Tujuan dari penelitian ini adalah untuk menguji secara empiris pengaruh variabel sifat machiavellian, locus of control dan independensi , terhadap perilaku etis auditor. Literatur menunjukkan bahwa individu dengan tingkat machiavellian tinggi dan lebih rendah tingkat penalaran etika cenderung kurang mandiri dan lebih cenderung setuju dengan perilaku yang tidak etis. Kemerdekaan dalam audit berarti mengambil sudut pandang yang tidak bias dalam pelaksanaan 'pengujian audit, evaluasi hasil, dan penerbitan laporan audit. Beberapa hipotesis yang dikembangkan untuk menyelidiki: pertama pengaruh sifat machiavellianism yang negatif terhadap sikap etis auditor. Kedua, hubungan antara locus of controll dan perilaku etis auditor. yang terakhir adalah hubungan antara independensi auditor dan perilaku etis auditor.

Penelitian ini menggunakan sampel staf auditor yang bekerja di Kantor Akuntan Publik (KAP) yang ada di kota Yogyakarta. Metode analisis yang digunakan dalam penelitian ini adalah metode regresi berganda, dengan metode ini dapat dilihat bagaimana pengaruh setiap variabel seperti sifat machiavellianisme, locus of 'controll,dan independensi terhadap perilaku etis auditor.

Hasil dari penelitian ini hipotesis satu dan tiga terbukti sedangkan hipotesis kedua tidak terbukti hal ini mungkin disebabkan karena auditor lebih memilih bekerja menggunakan katrampilan yang dimiliki dan tidak berdasarkan locus of controll diri 'mereka sendiri.

Kata kunci : Sifat Machiavellianisme, Locus Of Controll, dan Independensi, Perilaku Etis Auditor.

\begin{tabular}{|l|l}
\hline 1. PENDAHULUAN & \\
\hline Pada era globalisasi saat ini banyak terjadi kasus-kasus hukum yang
\end{tabular} melibatkan profesi akuntan. Berbagai kasus manipulasi akuntansi dan praktikpraktik profesi yang mengabaikan standar akuntansi bahkan etika telah 
menyebabkan merosotnya kepercayaan masyarakat khususnya masyarakat keuangan. Para pemakai laporan keuangan seperti investor dan kreditur mulai mempertanyakan kembali eksistensi akuntan publik sebagai pihak independen yang menilai kewajaran laporan keuangan (Selaswatija, 2007).

Salah satu kasus manipulasi pembukuan yang pemah terjadi dan cukup menggemparkan dunia bisnis adalah kasus Enron Corporation. Laporan keuangan yang sebelumnya dinyatakan wajar tanpa pengecualian oleh kantor akuntan Arthur Anderson yang merupakan salah satu kantor akuntan publik dalam jajaran Big Five, secara mengejutkan dinyatakan pailit. Sebagian pihak menyatakan kepailitan tersebut salah satunya karena kantor akuntan Arthur Anderson memberikan dua jasa sekaligus, yaitu sebagai auditor dan konsultan bisnis (Purnamasari, 2006).

Profesionalisme mensyaratkan tiga hal utama yang harus dimiliki oleh setiap anggota profesi yaitu : keahlian, pengetahuan dan karakter. Karakter menunjukan personality (kepribadian) seorang profesional diantaranya diwujudkan dalam sikap etis dan tindakan etis. (Marie, 2002 dalam Purnamasari dan Crismastuti, 2006). Sikap dan tindakan etis akuntan publik akan sangat menentukan posisinya dimasyarakat pemakai jasa profesionalisnya (Machfoed,1997 dalam Nugrahaningsih, 2005). Sejalan dengan itu, Khomsiyah dan Indriantoro (1998) menyatakan bahwa apabila seorang auditor melakukan tindakan-tindakan yang tidak etis, maka hal tersebut akan merusak kepercayaan masyarakat terhadap profesi auditor itu (Nugrahaningsih,2005).

Beberapa peneliti dan penulis baik dari luar dan dalam negeri telah meneliti dan membahas isu mengenai etika profesi khususnya auditor. Richmond (2003) dan purnamasari (2006) menemukan bukti bahwa kepribadian individu mempengaruhi perilaku etis. Hasil penelitian Richmond mendukung teori adanya ketrkaitan kepribadian mahasiswa akuntansi dengan perilaku mereka dalam menghadapi dilema etika. Nugraharingsih (2005) melakukan analisis perbedaan perilaku etis auditor di KAP dalam etika profesi studi terhadap peran faktor-faktor individual yaitu locus of control, lama pengalaman kerja, gender, dan equity sensitivity. Hasil penelitian mencapai kesimpulan bahwa terdapat perbedaan perilaku etis yang signifikan antara auditor internal locus of control dan auditor external locus of control. Purnamasari (2006) yang mereplikasi penelitian Richmond mencapai kesimpulan bahwa sifat machivellian berhubungan negatif dengan ndependensi dan perilaku etis auditor. Muawanah (2000) melakukan penelitian mengenai peran locus of control. Komitmen profesi dan kesadaran etis terhadap sikap etis auditor dengan hasil penelitian yang menunjukan interaksi antara variabel personalitas (locus of control dan komitmen profesi) dengan cognitive style (kesadaran etis) berpengaruh terhadap respon auditor dalam situasi konflik audit (Selaswatija, 2007). 


\section{Rumusan Masalah}

Berdasarkan uraian latar belakang tersebut, maka penelitian ini bertujuan untuk menjawab permasalahan mengenai hubungan kepribadjan auditor dengan perilaku mereka dalam menghadapi dilema-dilema etika. Adapun rumusan masalah dalam penelitian ini adalah sebagai berikut:

Apakan sifat machiavellian, locus of control dan independensi mempengaruhi perilaku etis auditor.

\section{Tujuan Penelitian}

Berdasarkan rumusan masalah diatas, maka tujuan dari penelitian ini adalah untuk menguji secara empiris pengaruh variabel sifat Machiavellian, locus of controldan independensi terhadap perilaku etis auditor.

\section{Manfaat Penelitian}

Adapun manfaat yang diharapkan dari penelitian ini adalah:

1.Untuk mengetahui pengaruh sifat Machiavellian, locus of control dan independensi terhadap perilaku etis auditor.

2.Untuk mengembangkan dan menambah wawasan penulis berkaitan dengan masalah yang diteliti.

3.Sebagai bahan rujukan atau referensi untuk penelitian selanjutnya yang terkait dengan akuntansi keperlakuan khususnya mengenai etika profesi.

\section{TINJAUAN PUSTAKA}

\subsection{Sifat Machiavellian}

Paham machiavellian diperkenalkan oleh seorang ahli filsuf politik dari Itali bernama Niccolo Machiavellian (1469-1572). Machiavellianisme didefinisikan sebagai sebuah proses dimana manipulator mendapatkan lebih banyak reward dibandingkan yang dia peroleh ketika tidak melakukan manipulasi dan ketika orang lain mendapatkan lebih kecil minimal jangka pendek. (Christie dan Geis, 1980 dalam Purnamasari, 2004) sifat machiavellian diperkirakan menjadi konstruk tambahan yang mempengaruhi seseorang untuk berperilaku tidak etis atau membantu menstimulus perbedaan perilaku etis. Individu dengan sifat machiavellian tinggi cenderung lebih sering berbohong, kurang bermoral, dan lebih manipulatif. (Mc Laughlin, 1970 dalam Purnamasari,2006). 


\subsection{Locus Of Control}

Dalam literatur akuntansi, locus of control telah banyak diteliti misalnya dalam kaitanya dengan partisipasi anggaran (Bownel, 1982 dalam Frucot dan Shaeron, 1991), karakteristik informasi (Fisher, 1996) dan prilaku etis (Trevino, 1986 dalam Selaswatija, 2007).

Menurut Brownel (1982) locus of control adaiah cara pandang seseorang terhadap suatu peristiwa apakah dia dapat atau tidak dapat meghasilkan (control) atas peristiwa yang terjadi padanya (Permatasari, 2006). Reiss dan Mitra (1998) membagi locus of control menjadi dua, yaitu internal locus of control adalah cara pandang bahwa segala hasil yang diperoleh baik atau buruk adalah karena tindakan, kapasitas dan faktor-faktor dari dalam diri mereka sendiri. External locus of control - adalah cara pandang bahwa segala hasil yang diperoleh, baik atau buruk berada diluar kontrol diri mereka tetapi karena faktor luar seperti keberuntungan, kesempatan, dan takdir. Individu yang termasuk dalam kategori ini meletakan tanggung jawab diluar kendalinya (Nugrahaningsih, 2005).

\subsection{Independensi}

Independensi akuntan publik mencakup dua aspek, yaitu independensi sikap mental (independence in pact) dan independensi penampilan (independence in appearance). Independensi sikap mental berarti adanya kejujuran di dalam diri akuntan dalam mempertimbangkan fakta-fakta dan adanya pertimbangan yang objektif tidak memihak di dalam diri akuntan dalam menyatakan pendapatnya. Independensi penampilan berarti adanya kesan masyarakat bahwa akuntan publik bertindak independen sehingga akuntan publik harus menghindari faktorfaktor yang dapat mengakibatkan masyarakat meragukan kebebasanya. Independensi penampilan berhubungan dengan persepsi masyarakat terhadap independensi akuntan publik (Mautz, 1961 dalam Trisnaningsih, 2007).

\subsection{Perilaku Etis}

Perilaku yang beretika dalam organisasi adalah melakukan tindakan secara fair sesuai hukum konstitusional dan peraturan pemerintah yang dapat diaplikasikan (Steiner dalam Nugrahaningsih, 2005), Harsono (1997) menyimpulkan bahwa etika adalah hal-hal yang berkaitan dengan masalah benar dan salah. Etika profesi merupakan etika khusus menyangkut dimensi sosial yang berlaku dalam kelompok profesi yang bersangkutan (Nugrahaningsih, 2005). Perilaku etis juga 
merupakan komponen dari kepemimpinan, yang mana pengembangan etika adalah hal penting bagi kesuksesan individu. sebagai pemimpin suatu organisasi (Morgan, 1993 dalam Nugrahaningsih, 2005). Larkin (2000) juga menyatakan bahwa kemampuan untuk dapat mengidentifikasi perilaku etis dan tidak etis sangat berguna dalam semua profesi termasuk auditor (Nugrahaningsih, 2005).

\subsection{Penelitian-penelitian terdahulu}

Penelitian terdahulu banyak dilakukan untuk meneliti sifat machiavellian dan kecenderungan sikap etis pada profesi-profesi bisnis. Jones dan Kavanagh (1996) menemukan bahwa skala mach tinggi cenderung bertindak tidak etis dibandingkan skala mach rendah. Penelitian Corzine (1999) menemukan bahwa US Bankers memiliki skala mach yang relatif rendah. Penelitian ini juga mengungkapkan bahwa bankers yang memiliki skala mach tinggi pada umumnya merasa bahwa peraturan perbankan yang ketat membatasi kemampuan perusahaan untuk maju (Selaswatija, 2007). Tumbell (1976) menemukan bahwa seseorang yang memiliki skor mach tinggi mempunyai kecenderungan untuk mengekploitasi keadaan guna keuntungan diri sendiri (Selaswatija, 2007). Ghosh dan Grain (1996) menemukan indikasi bahwa mahasiswa bisnis dengan skor mach yang rendah cenderung mempunyai keinginan untuk tidak taat (Selaswatija, 2007).

Nugrahaningsih (2005) mengadakan penelitian tentang efek dari perbedaan faktor individual dalam kemampuan menerima perilaku etis atau tidak etis. Hasil penelitian menunjukan bahwa individu dengan internal locus of control lebih cenderung tidak menerima tindakan tertentu yang kurang etis, sedangkan individu dengan external locus of control cenderung lebih menerima tindakan tertentu yang kurang etis.

Fauzi (2001) melakukan penelitian mengenai pengaruh perbedaan faktor-faktor individual terhadap perilaku etis mahasiswa. Faktor-faktor individual yang diteliti berupa locus of control, disiplin akademis, pengalaman kerja, dan equity sensitivity. Hasil pengujian ini kuisioner dengan penelitian sebelumnya yang menunjukan bahwa mahasiswa akuntansi dengan internal locus of control berperilaku lebih etis daripada mahasiswa akuntansi dengan external locus of control (Selaswatija, 2007). 


\section{Kerangka Konseptual}

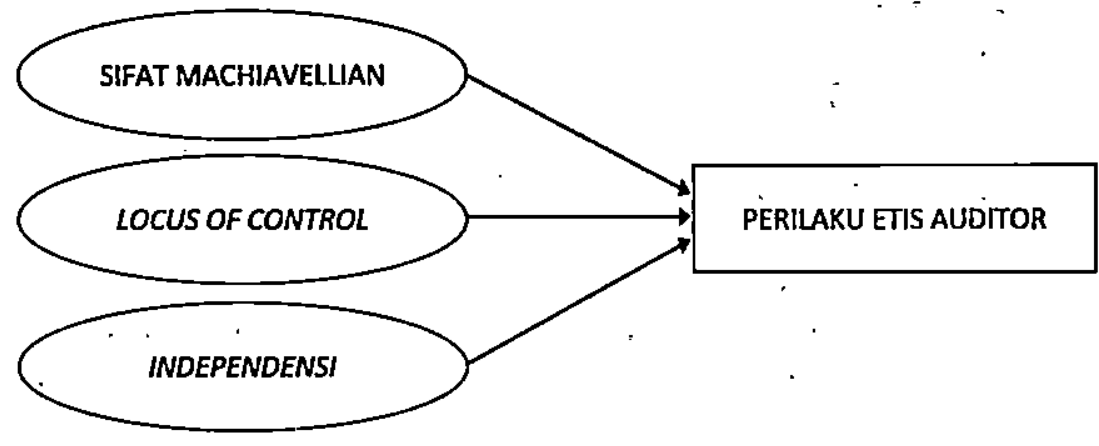

\section{Hipotesis}

Berdasarkan uraian di atas, maka hipotesis dalam penelitian ini yaitu:

H1 : Sifat mchiavellian berpengaruh secara negatif terhadap perilaku etis auditor.

$\mathrm{H} 2$ : Locus of control berpengaruh secara positif.terhadap perilaku etis auditor.

H3 : Independensi berpengaruh secara positif terhadap perilaku etis auditor.

\section{Metode Penelitian}

\subsection{Populasi, Sampel dan Metode Pengambilan Sampel}

Populasi dalam penelitian ini adalah staf audit yang bekerja pada Kantor Akuntan Publik di kota Yogyakarta sebagaimana yang terdaftar pada Direktori lkatan Akuntansi Publik Indonesia (IAPI).

Untuk menentukan sampel dalam penelitian ini menggunakan non probability sampling, dengan teknik convenience sampling. Metode ini memilih sampel dari elemen populasi (orang atau kejadian) yang datanya mudah diperoleh peneliti (Indriantoro dan Supomo, 1999 dalam Selaswatija, 2007). Dalam penelitian ini sampel yang digunakan adalah staf audit yang bekerja pada delapan Kantor Akuntan Publik di Yogyakarta.

\subsection{Jenis dan Sumber Data}

Data yang diperoleh langsung dari responden berupa jawaban terhadap kuisioner. Jawaban atas pertanyaan bersifat kualitatif dikuantitatifkan, disusun menggunakan skala likert dengan poin 1 (sangat tidak setuju) sampai 5 (sangat setuju). 


\subsection{Definisi Operasional dan Pengukuran Variabel}

- Variabel terikat atau dependen $(Y)$, yaitu perilaku etis

Variabel dependen yang akan diteliti dalam penelitian ini adalah perilaku etis. Perilaku yang beretika dalam organisasi adalah melaksanakan tindakan secara fair sesuai hukum konstitusional dan peraturan pemerintah yang dapat di aplikasikan (Steiner dalam Nugrahaningsih, 2005:619).

Pengukuran variabel perilaku etis menggunakan instrumen ethical rating (erating)

- Variabel Bebas atau Independen $(\mathbf{X})$ yang terdiri dari: Sifat Machiavellian

Sifat Machiavellian merupakan suatu keyakinan atau persepsi yang diyakini tentang hubungan antar personal. Kepribadian machiavellian dideskripsikan sebagai kepribadian yang kurang mempunyai afeksi dalam hubungan personal, mengabaikan moralitas konvensional, dan memperlihatkan komitmen ideologi yang rendah, sehingga mempunyai kecenderungan untuk memanipulasi orang lain.

\section{Locus of Control}

Locus of control dioperasionalisasikan sebagaj konstruk internal-eksternal yang mengukur keyakinan seseorang atas kejadian yang menimpa kehidupannya. Locus of control merupakan tingkatan seseorang mampu menerima tanggungjawab pribadi terhadap apa yang terjadi dalam diri mereka sendiri. Variabel locus of control diukur dengan instrumen The Work Locus of Control(WLCS).

\section{Independensi}

Independensi auditor merupakan dasar utama kepercayaan masyarakat pada profesi akuntan publik dan merupakan salah satu faktor yang sangat penting untuk menilai mutu jasa audit.

Variabel independensi auditor dalam penelitian ini diukur menggunakan instrumen yaitu: independensi penyusunan progam, independensi investigatif, dan independensi pelaporan.

\section{Pengujian Hipotesis}

Șebelum dilakukan uji hipotesis, terlebih dahulu dilakukan uji validitas, reliabilitas dan uji asumsi klasik. 
Untuk mengetahui pengaruh variabel sifat machiavellian, locus of control dan independensi terhadap perilaku etis auditor dalam situasi dilema. Analisis regresi berganda digunakan untuk pengujian hipotesis 1,2 , dan 3 . Model persamaan regresi tersebut adalah sebagai berikut:

$$
Y_{2}=\alpha+\beta_{1} X_{1}+\beta_{2} X_{2}+\beta_{3} X_{3}+e
$$

Dimana : a : Konstanta

$$
\begin{array}{ll}
\beta & \text { : Koefisien regresi } \\
Y_{1} & \text { : Perilaku Etis Auditor } \\
X_{1} & \text { : Sifat Machiavellian } \\
X_{2} & \text { : Locus of Control } \\
X_{3} & : \text { Independensi } \\
e & : \text { Error }
\end{array}
$$

Pengujian hipotesis dalam penelitian ini diuraikan sebagai berikut:

Uji keberartian masing-masing koefisien regresi atau disebut dengan uji T (uji parsial/koefisien regresi), yaitu untuk mengetahui apakah nilai-nilai koefisien tersebut mempunyai pengaruh signifikan atau tidak sehingga dapat diambil langkah efektif dengan menambah atau mengurangi variabel-variabel bebas yang dugunakan untuk model regresi yang dibuat (Febriyanti, 2005). Dalam penelitian ini menggunakan tingkat alfa sebesar $5 \%$.

\section{Analisis dan Pembahasan.}

\subsection{Populasi, Sampel dan Metode Pengambilan Sampel}

Berikut ini adalah hasil dari penyebaran kuesioner:

Tabel 1

Hasil Penyebaran Kuesioner

\begin{tabular}{|c|l|c|c|}
\hline No & \multicolumn{1}{|c|}{ Kantor KAP } & Jumlah yang disebar & Jumlah yang kembali \\
\hline 1 & $\begin{array}{l}\text { KAP. Doli Bambang, Sudamadji \&. Dadang } \\
\text { (Cab) }\end{array}$ & 10 & 4 \\
\hline 2 & KAP. Abdul Muntolib & 10 & 6 \\
\hline 3 & KAP. Drs. Hadjono & 9 & 0 \\
\hline 4 & KAP. Drs. Henry Susanto & 7 & 7 \\
\hline 5 & KAP. Kumala Hadi & 10 & 10 \\
\hline 6 & KAP. Drs. Soeroso Dono Sapoetro, MM & 9 & 2 \\
\hline 7 & KAP. Hadori \& Rekan & 10 & 4 \\
\hline 8 & KAP. Drs. Inaresjz Kemalawarta & 5 & 0 \\
\hline & Total & 70 & 33 \\
\hline
\end{tabular}




\subsection{Karakteristik Responden}

Karakteristik responden yang dianalisis dalam penelitian ini meliputi, jenis kelamin, pendidikan, kedudukan KAP, dan lama bekerja. Karakteristik responden tersebut dapat dijelaskan sebagai berikut:

Berdasarkan hasil jawaban responden tentang jenis kelamin dapat disajikan pada tabel berikut:

Tabel 2

Klasifikasi Responden berdasarkan Jenis Kelamin

\begin{tabular}{|l|c|c|c|}
\hline Pendidikan terkahir & Jumlah & Persentase & \\
\hline Pria & 18 & $54.5 \%$ & \\
\hline Wanita & 15 & $45.5 \%$ & \\
\hline Jumlah & 33 & $100.0 \%$ & \\
\hline
\end{tabular}

Dari Tabel 2 diatas menunjukan bahwa mayoritas responden adalah berjenis kelamin pria Hal ini disebabkan karena sebagian besar pimpinan perusahaan dalam merekrut auditor masih didominasi oleh kaum pria, dimana kelompok responden ini memiliki ketegasan dalam pengambilan keputusan, dibandingkan dengan kaum wanita termasuk dalam melaksanakan audit laporan keuangan sehingga akan berpengaruh terhadap kinerja auditor.

Berdasarkan hasil jawaban terhadap pendidikan terakhir responden dapat disajikan dalam bentuk tabel berikut:

Tabel 3

Pendidikan Terakhir Responden

\begin{tabular}{|c|c|c|}
\hline Pendidikan Responden & Frekuensi & Persentase \\
\hline SLTA & 0 & $0.0 \%$ \\
\hline S1 & 23 & $69.7 \%$ \\
\hline S2 & 10 & $30.3 \%$ \\
\hline S3 & 0 & $0.0 \%$ \\
\hline Total & 33 & $100.0 \%$ \\
\hline
\end{tabular}

Berdasarkan tabel di atas dapat diketahui bahwa sebagian besar responden berpendidikan terakhir $\mathrm{S} 1$. Hal ini berarti sebagian besar responden berpendidikan tinggi, sehingga mampu menjalankan profesinya sebagi seorang akuntan dengan baik dan berkomitmen pada kode etik akuntan.

Jabatan auditor terbagi dalam empat kelompok yaitu partner, manjer, senior dan yunior. Hasil karakteristik responden berdasarkan jabatan dapat ditunjukkan pada tabel berikut: 
Tabel.4

Kedudukan di KAP

\begin{tabular}{|c|c|c|}
\hline Jabatan & Jumlah & Persentase \\
\hline Partner & 0 & 0 \\
\hline Manajer & 9 & $27.3 \%$ \\
\hline Senior & 4 & $12.1 \%$ \\
\hline Yunior & 20 & $60.6 \%$ \\
\hline Total & 33 & $100.0 \%$ \\
\hline
\end{tabular}

Berdasarkan tabel di atas menunjukkan bahwa mayoritas auditor yang dijadikan responden dalam penelitian ini memiliki jabatan sebagai yunior auditor yaitu sebanyak 20 orang Hal ini berarti mayoritas auditor yang dijadikan responden adalah auditor yunior.

Hasil deskripsi tentang responden berdasarkan lama bekerja dapat dilihat dalam tabel berikut:

Tabel.5.

Lama Bekerja

\begin{tabular}{|c|c|c|}
\hline Masa Kerja & Frekuensi & Persentasє \\
\hline$<1$ tahun & 9 & $27.3 \%$ \\
\hline $1-5$ tahun & 18 & $54.5 \%$ \\
\hline$>5$ tahun & 6 & $18.2 \%$ \\
\hline Total & 33 & $100.0 \%$ \\
\hline
\end{tabular}

Berdasarkan tabel di atas menunjukkan bahwa mayoritas auditor yang bekerja pada Kantor Akuntan Publik di Yogyakarta antara 1- 5 tahun yaitu sebanyak 18 responden atau 54,5\%. Hasil diatas dapat dimaknakan bahwa rata-rata Auditor telah bekerja cukup lama, dalam menggeluti profesinya sebagai auditor sehingga telah memiliki pengalaman yang cukup besar, termasuk dalam menjaga perilaku etis sebagai auditor.

\subsection{Deskriptif Variabèl Penelitian}

Analisis ini menjelaskan tentang deskriptif penilaian responden terhadap variabel penelitian yang terdiri dari sifat machiavellin, locus of control, independensi, dan perilaku etis. Penilaian terhadap variabel penelitian ini diukur dengan skor terendah 1 (sangat tidak setuju), dan skor tertinggi adalah 5 (Sangat setuju). Sehingga dalam menentukan kriteria penilaian konsumen terhadap variabel penelitian dapat dilakukan dengan interval sebagai berikut: 
Skor persepsi terendah adalah : 1

Skor persepsi tertinggi adalah : 5

Interval $=\frac{5-1}{4}=1$

Sehingga diperoleh batasan persepsi adalah sebagai berikut:

$1,00-2,00$

= Sangat rendah

$2,01-3,00$

$=$ Rendah

$3,01-4,00$

$=$ Tinggi

$4,01-5,00$

= Sangat Tinggi

Hasil analisis deskriptif terhadap variabel penelitian dapat ditunjukkan dengan tabel berikut:

Tabel 6

Descriptive Statistics

\begin{tabular}{|c|c|c|c|}
\hline & $\mathrm{N}$ & & Std. Deviation \\
\hline Sifat Machiavellian & 33 & 3.6227 & .73846 \\
\hline Locus of Control & 33 & 3.6104 & .68816 \\
\hline Independensi & 33 & 3.3306 & .86895 \\
\hline Perilaku etis & 33 & 3.2235 & 1.12142 \\
\hline Valid N (listwise) & 33 & &. \\
\hline
\end{tabular}

Dari Tabel.6 dapat diketahui tanggapan dari 33 responden rata-rata memiliki penilaian yang tinggi terhadap sifat machiavellin, yang ditunjukkan dengan nilai rata-rata sebesar 3,6227 yang berada pada interval 3,01-4,00. Hal ini disebabkan karena auditor tidak pernah mengatakan pada orang lain alasan yang sebenarnya, kecuali jika dibutuhkan, cara mengendalikan orang lain dengan mengatakan apa yang ingin mereka dengar, semua orang memiliki sifat jahat yang muncul jika diberi kesempatan, kejujuran adalah hal terbaik, orang yang dapat maju jika memiliki moral yang baik, dan kebanyakan orang orang adalah pemberani.

Dari Tabel 6 dapat diketahui tanggapan dari 33 auditor pada KAP di Yogyakarta rata-rata memiliki penilaian yang tinggi terhadap Locus of Control, yang ditunjukkan dengan nilai rata-rata sebesar 3,6104 yang berada pada interval $3,01-4,00$, yang berarti penilaian berada dalam kriteria yang tinggi. $\mathrm{Hal}$ ini disebabkan karena auditor pada setiap penugasan bisa menyelesaikan tugas tersebut dengan baik, memperoleh penugasan merupakan keberuntungan, menghasilkan banyak uang merupakan nasib baik, melaksanakan tugas dengn baik jika mau berusaha, memperoleh promosi karena nasib baik dan jika melaksanakan tugas dengan baik, anggota tim memiliki pengaruh terhadap pimpinan, dan jika bekerja dengan baik maka akan mendapatkan penghargaan.

Dari Tabel 6 dapat diketahui tanggapan dari 33 auditor pada KAP di Yogyakarta rata-rata memiliki penilaian yang tinggi terhadap Independensi, yang ditunjukkan dengan nilai rata-rata sebesar 3,3306 yang berada pada interval $3,01-4,00$, yang berarti penilaian berada dalam kriteria yang tinggi. $\mathrm{Hal}$ 
ini disebabkan karena auditor dalam menyusun program audit bebas dari campur tangan orang lain, pemerikasaan langsung dan bebas (mengakses semua buku, catatan, pejabat, karyawan, perusahaan), pelaporan bebas dari kepentingan pribadi dan perasaan kewajiban untuk memodifikasi pengaruh fakta - fakta serta dalam penafsirannya.

Hasil deskriptif terhadap variabel perilaku etis auditor memiliki nilai rata-rata sebesar 3,2235 . Hal ini berarti rata-rata perilaku etis auditor di Yogyakarta termasuk dalam kriteria yang tinggi karena berada pada interval $3,01-4,00$. Hasil ini menunjukkan bahwa auditor telah memiliki kode etik yang baik, baik secara pelaksanaan, penafsiran maupun penyempurnaan kode etiknya.

\subsection{Hasil Uji Hipotesis}

Setelah terbukti valid dan reliabel serta lolos dari uji asumsi klasik, maka dilakukan pengujian hipotesis. Hasil pengujian terhadap model regresi berganda terhadap variabel sifat machiavellian $\left(X_{1}\right)$, locus of control dan $\left(X_{2}\right)$, independensi $\left(X_{3}\right)$, yang mempengaruhi perilaku etis auditor dilihat dalam tabel 7 berikut:

Tabel 7

\section{Hasil Regresi Linier Berganda}

\begin{tabular}{|c|l|c|c|c|c|c|}
\hline \multirow{2}{*}{ Model } & & \multicolumn{2}{|c|}{ Unstandardized Coeficients } & Standardized Coeficients & \multirow{2}{*}{ T } & \multirow{2}{*}{ Sig. } \\
\cline { 3 - 7 } & & $\mathrm{B}$ & Std. Error & Beta & & \\
\hline \multirow{3}{*}{1} & Constant & 2.045 & 1.022 & & 2.000 & 0.055 \\
\cline { 2 - 7 } & Machiavellian & -0.810 & 0.333 & -2.434 & 0.021 \\
\cline { 2 - 7 } & Locus of control & 0.664 & 0.375 & 0.533 & 1.769 & 0.087 \\
\cline { 2 - 7 } & Independensi & 0.515 & 0.214 & 0.399 & 2.414 & 0.022 \\
\hline
\end{tabular}

Pada penelitian ini digunakan model persamaan regresi linear berganda sebagai berikut:

$$
Y=a+b_{1} X_{1}+b_{2} X_{2}+b_{3} X_{3}
$$

Dengan memperhatikan model regresi dan hasil regresi linear berganda maka didapat persamaan faktor-faktor yang mempengaruhi Perilaku etis auditor sebagai berikut:

$$
Y=2.045-0.810 X_{1}+0.664 X_{2}+0.515 X_{3}
$$

\section{Hasil Uji Hipotesis 1}

Hasil pengujian signifikansi menunjukkan bahwa variabel sifat machiavellian $\left(X_{1}\right)$ terdapat nilai probabilitas sebesar 0.021 yang berarti $p$ value $<0,05$. Nilai tersebut berarti bahwa variabel sifat Machiavellian berpengaruh secara negatif dan signifikan (kuat) terhadap perilaku etis auditor, dengan demikian hipotesis pertama terbukti.

Penelitian ini sesuai dengan penelitian yang dilakukan oleh Jones dan Kavanagh (1996) dan Richmond (2003) yang menemukan individu dengan sifat machiavellin tinggi akan lebih mungkin melakukan tindakan yang tidak etis 
dibandingkan individu dengan sifat machiavellin rendah.

Sifat machiavellin merupakan suatu keyakinan atau persepsi yang diyakini tentang hubungan antar personal. Persepsi ini akan membentuk suatu kepribadian yang mendasari sikap dalam berhubungan dengan orang lain. Kepribadian machiavellin dideskripsikan sebagai kepribadian yang kurang mempunyai afeksi dalam hubungan personal, mengabaikan moralitas konvensional, dan memperlihatkan komitmen ideologi yang rendah, sehingga mempunyai kecenderungan untuk memanipulasi orang lain. Berbeda dengan profesi - profesi bisnis, kepribadian machiavellin justru menjadi ancaman bagi profesi akuntan. Profesi akuntan dituntut untuk mempunyai tanggung jawab etis yang lebih daripada 'tanggung jawab profesi lainnya.

\section{.Hasil Uji Hipotesis 2}

Hasil pengujian signifikansi menunjukkan bahwa variabel locus of control $\left(X_{2}\right)$ 'terdapat nilai probabilitas sebesar 0.087 yang berarti $0.087>0,05$. Nilai tersebut dapat membuktikan bahwa variabel locus of control berpengaruh secara positif tetapi tidak signifikan terhadap perilaku etis auditor, dengan demikian|hipotesis kedua tidak terbukti.

Locus of control tidak berpengaruh secara signifikan terhadap perilaku etis. Hal ini mungkin disebabkan karena banyaknya faktor-faktor yang mempengaruhi sikap etis auditor sehingga locus of control dari auditor tidak mempengaruhi secara signifikan terhadap perilaku etisnya. hal ini senada dengan pemyataan dari Trevino 'dan Youngblood (1990) yang menyatakan bahwa terdapat dua pandangan mengenai faktor-faktor yang mempengaruhi tindakan tidak etis yang dibuat oleh seorang individu. Pertama, pandangan yang berpendapat bahwa tindakan atau pengambilan keputusan tidak etis lebih dipengaruhi oleh karakter moral individu. Kedua, tindakan tidak etis lebih dipengaruhi oleh lingkungan misalnya reward dan punishment perusahaan, iklim etis organisasi dan sosialisasi kode etik profesi oleh organisasi dimana individu tersebut bekerja (Pumamasari, 2006)

i

\section{Hasil Uji Hipotesis 3}

Hasil pengujian signifikansi menunjukkan bahwa variabel independensi $\left(X_{3}\right)$ terdapat nilai probabilitas sebesar 0.022 yang berarti $p_{\text {value }}<0,05$. Nilai tersebut dapat membuktikan bahwa variabel independensi berpengaruh secara positif dan șignifikan (kuat) terhadap Perilaku etis auditor, dengan demikian hipotesis ketiga terbukti.

Hasil ini disebabkan karena independensi berarti adanya kejujuran dalam diri auditor dalam mempertimbangkan fakta dan adanya pertimbangan yang obyektif tidak memihak dalam diri auditor dalam memutuskan dan menyatakan pendapatnya (Trisnaningsih, 2007). Nilai dari pengauditan tergantung besarnya persepsi publik 
terhadap indepedensi auditor, sehingga tidak mengherankan jika indepedensi merupakan hal utama dalam kode etik profesi akuntan (Arens dan Loebbecke, 2000) dalam Purnamasari, 2006). Idepedensi merupakan salah satu nilai etis yang dijabarkan secara tertulis bagi seorang auditor sebagai panduan agar dapat selalu berperilaku etis. Sehingga diprediksikan bahwa semakin indepeden seorang auditor maka auditor tersebut akan semakin dapat berilaku etis.

Kemudian untuk menunjukkan berapa persen perilaku etis auditor yang dapat dijelaskan oleh ketiga variabel bebasnya dapat dilihat dari Tabel 8 dibawah ini :

Tabel 8

Hasil Uji Koefisien Determinasi

Model Summary

\begin{tabular}{|l|r|r|r|r|r|}
\hline Mode & \multicolumn{1}{|c|}{ R } & R Square & $\begin{array}{c}\text { Adjusted } \\
\text { R Square }\end{array}$ & $\begin{array}{c}\text { Std. Error of } \\
\text { the Estimate }\end{array}$ & $\begin{array}{c}\text { Durtin- } \\
\text { Watson }\end{array}$ \\
\hline 1 & $.566^{\circ}$ & .323 & .253 & .96947 & 1.168 \\
\hline
\end{tabular}

a Predictors: (Constant), Independensi, Sifat Machiavelian, Locus of Control

b. Dependent Variable: Perilaku etis

Dari tabel 8 dapat diketahui koefisien determinasi $\left(R^{2}\right)$ sebesar 0,317. Dengan nilai koefisien determinasi sebesar 0,323 , maka dapat diartikan bahwa $32,3 \%$ perilaku etis dapat dijelaskan oleh ketiga variabel bebas yang terdiri sifat machiavellian, locus of control dan independensi. Sedangkan sisanya sebesar $67,7 \%$ dipengaruhi oleh variabel lain yang tidak dimasukkan dalam model penelitian.

8. Kesimpulan, Keterbatasan, dan Saran.

\subsection{Kesimpulan}

Berdasarkan hasil penelitian seperti yang telah diuraikan pada bab sebelumnya dapat ditarik beberapa kesimpulan. Pertama, sifat machiavellian mempunyai pengaruh yang signifkan negatif terhadap Perilaku etis auditor, hal ini menunjukkan bahwa semakin tinggi sifat machiavellian maka semakin rendah perilaku etis auditor, demikian juga sebalinya semakin rendah sifat machiavellian maka semakin tinggi perilaku etis auditor. Kedua, locus of control mempunyai pengaruh positif tetapi tidak signifkan terhadap Perilaku etis auditor, hal ini berarti bahwa tinggi rendah locus of control pada diri seorang auditor maka tidak akan mempengaruhi perilaku etisnya sebagai seorang auditor. Ketiga, independensi mempunyai pengaruh yang signifkan positif terhadap Perilaku etis auditor, hal ini berarti bahwa semakin tinggi independensi maka perilaku etis auditor juga semakin meningkat. 


\subsection{Keterbatäsan Penelitian}

Ada beberapa keterbatasan dalam penelitian ini, yang kemungkinan dapat menimbulkan bias atau ketidakakuratan pada hasil penelitian ini. Pertama, hasil penelitian ini hanya dapat dijadikan analisis pada obyek penelitian yang terbatas profesi auditor pada kantor akuntan publik di wilayah Yogyakarta, sehingga memungkinkan adanya perbedaan hasil dan kesimpulan apabila dilakukan untuk obyek dan profesi yang berbeda. Kedua, masih terdapat responden yang bekerja di KAP dalam hitungan bulan dan hari sehingga pengalaman kerja responden di KAP masih tergolong sedikit.

\subsection{Saran}

Penelitian ini menyarankan sbb:

1. Bagi peneliti selanjutnya hendaknya melakukan penelitian yang sama yang didukung dengan melakukan oberservasi yang lebih banyak melalui keterlibatan di Akuntan Publik, misalnya dengan cara melakukan studi Kuliah Lapangán (KL) pada kantor Akuntan Publik

2. Sebaiknya penelitian ini dikembangkan dengan sampel yang lebih luas misalnya untuk kota-kota besar seperti Jakarta dan Surabaya sehingga job dari auditor merupakan audit laporan keuangan pada perusahaan-perusahaan besar, sehingga perilaku etis auditor tersebut lebih representatif.

3. Penelitian selanjutnya diharapkan untuk menambah variabel lain yang mempengaruhi perilaku etis auditor misalnya reward dan punishment perusahaan. 


\section{DAFTAR PUSTAKA}

Algifari, 2000. Analisis Regresi: Teori, kasus dan solusi. Edisi 2, yogyakarta: BPFE.

Arikunto, Suharsimi, 2002. Prosedur Penelitian Suatu Pendekatan Praktek. Jakarta: Rineka Cipta.

Chrismastuti, Agnes A dan ST Vena Purnamasari, 2004. Hubungan sifat Macheavellian, Pembelajaran etika dalam mata kuliah Etika dan Sikap Etis Akuntan: (Suatu Analisis Perilaku Etis Akuntan dan Mahasiswa Akuntansidi Semarang) Simposium Nasional akuntansi VII, Denpasar Bali.

Crain, William, 2007. Teori Perkembangan. Yogyakarta: Pustaka Pelajar

Engko, Cecilia dan Gudono. 2007. Pengaruh Komplesitas Tugas Dan Locus Of Control Terhadap Hubungan Antara Gaya Kepemimpinan dan Kepuasan Kerja Auditor. Simposum Nasional AkuntansiX, Makassar.

Febrianty, Medina. 2005. Analisis Hubungan' Stakeholder Dengan Tanggungjawab Sosial Perusahaan dan Pengaruhnya Terhadap Akuntansi Sosial (Studi Empiris Pada Industri Sedang dan Besar Di Kota Makassar). Skripsi FEUnhas.

Febrisanti, Dewi. 2006. Pengaruh Locus Of Control, Komitmen Profesi dan Kesadaran Etis Terhadap Perilaku Auditor. Skripsi FE-Unhas.

Hasan,M lqbal. 2002. Pokok-pokok Materi Metodologi Penelitian dan Aplikasinya. Jakarta: Ghalia Indonesia.

Ikatan Akuntan Indonesia, Kompartemen Akuntan Publik. 2001. Standar Umum ke Dua StandarProfesiAkunttan Publik. Jakarta : Salemba Empat.

Ikhsan, Harfan dan Ishak Muhammad. 2005. Akuntansi Keperilakuan. Jakarta : Salemba Empat.

Indriantoro, Nur dan Bambang Supomo. 1999. Metode Penelitian Bisnis Untuk Akuntansi dan Manajemen. Edisi Pertama, PP BPFE Yogyakarta : Yogyakarta. 
Irawati, Yuke dan Thio Anastasia Petrolina M. 2005. Hubungan Karakteristik Personal Auditor Terhadap Tingkat Penerimaan Penyimpangan Perilaku Dalam Audit. Simposium NasionalAkuntansi VIII. Solo.

Jogiyanto, H. M. 2004. Metodologi Penelitian Bisnis : Salah Kaprah dan PenglamanPengalaman. Yogyakarta: BPFE-UGM.

Jones, Gwen E. and Michael J Kavanagh.1996. An Experimental Examiation of The Effect of Individual and Situasional Factor on Unethical Behaviour Intention in The Workplace. Journal of Bussines Ethies. Vol 15:511-523.

Keraf, A. Sonny. 1998. Etika Bisnis Tuntutan dan Relevansinya, Edisi baru. Yogyakarta: Penerbit Kanisius.

Khomsiyah dan Nur Indriantoro. 1993. Pengaruh Orientasi Etika Terhadap Komitmen dan Sensitivitas etika Auditor Pemerintah di DKI Jakarta. Jurnal RisetAkuntansi Indonesia Vol 1 No. 1, Januari: 13-28.

Martadi, Indiana Farid dan Sri Suranta. 2006. Persepsi Akuntan Mahasiswa Akuntansi. Dan Kryawan Bagian Akuntansi Dipandang dari Segi Gender terhadap Etika bisnis dan Etika Profesi (Studidi Wilayah Surakarta).

Muawanah, Umi. 2000. Perilaku Auditor dalam Situasi Konflik Audit, peran locus of control, Komitmen Profesi dan Kesadaran Etis. Simposium Nasional Akuntasi III, Malang.

I

Muthmainah, Siti.2006, Studi Tentang Perbedaan Tentang Perbedaan Evaluasi Etis, Intensi Etis (Ethical Intention) dan Orientsi Etis Dilihat dari Gender dan Disiplin IImu: Potensi Rekruitmen Staf Profesional pada Kantor Akuntan Publik. Simposium NasionalAkuntansi IX, Padang,

Nugrahaningsih, Putri. 2005. Analisis Perbedaan Perilaku Etis Auditor di KAPDalam Etika Profesi (Studi Terhadap Peran Faktor-Faktor Individual: Locus of control, Lama Pengalaman Kerja, Gender, dan Equity Sensitivity) Simposium Nasional Akuntansi VIII, Solo.

Permata sari, Shinta. 2006. Pengaruh Kapasitas Individu yang Diinteraksikan dengan Locus Of Control terhadap Badgetary Slack. Simposium Nasional Akuntansi IX, Padang. 
Purnamasari, St. Vena dan Agnes Advensia Chrismastuti. 2006. Dampak Reinforcement Contingency terhadap Hubungan Sifat Machiavellian dan Perkembangan Moral. Simposium Nasional Akuntansi IX, Padang.

Pumamasari, St Vena. 2006. Sifat Machiavellian dan Independensi: Anteseden Independensi dan Perilaku Etis Auditor, Simposium Nasional Akuntansi IX, Padang.

Santoso, Purbayu Budi dan Ashari. 2005. Analisis Statistik dengan Microsoft Exel \& SPSS. Yogyakarta:ANDI Yogyakarta.

Santoso, Singgih. 2006. Menguasai Statistik di Era Informasi dengan SPSS 14.0. Jakarta: PTElex Media Komputindo.

Selaswatija, Arifah Budi. 2007. Pengaruh Sifat Machiavellian, Locus Of control dan Independensi Terhadap Perilaku Etis Auditor (Studi empiris Pada Kantor Akuntan Publik di Kota Makasar). Skripsi FE-Unhas.

Sulaiman, Wahid. 2004. Analisis Regresi Menggunakan SPSS: Contoh Kasus dan Pemecahanya. Yogyakarta:ANDI Yogyakarta.

Trisnaningsih, Sri. 2007. Independensi Auditor dan Komitmen Organisasi Sebagai Mediasi Pengaruh Pemahaman Good Governance. Gaya Kepemimpinan dan Budaya Organisasi Terhadap Kinerja Auditor. Simposium Nasional Akuntansi X, Makasar.

Umar, Husein. 2003. Metode Penelitian Untuk Skripsi dan Tesis Bisnis. Jakarta . PT. Raja Grafindo Persada.

Utami, Wiwik dan Fitri Indriawati. 2006. Muatan Etika dalam Pengajaran Akuntansi Keuangan dan Dampaknya Terhadap Persepsi Etika Mahasiswa: Studi Eksperimen Semu. Simposium Nasional Akuntansi IX, Padang.

Wilopo, 2006. Analisis Faktor-Faktor yang Berpenganuh Terhadap KecenderunganKecenderungan Akuntansi : Studi pada Perusahaan Publik dan Badan Usaha Milik Negara di Indonesia. Simposium Nasional Akuntansi IX, Padang. 


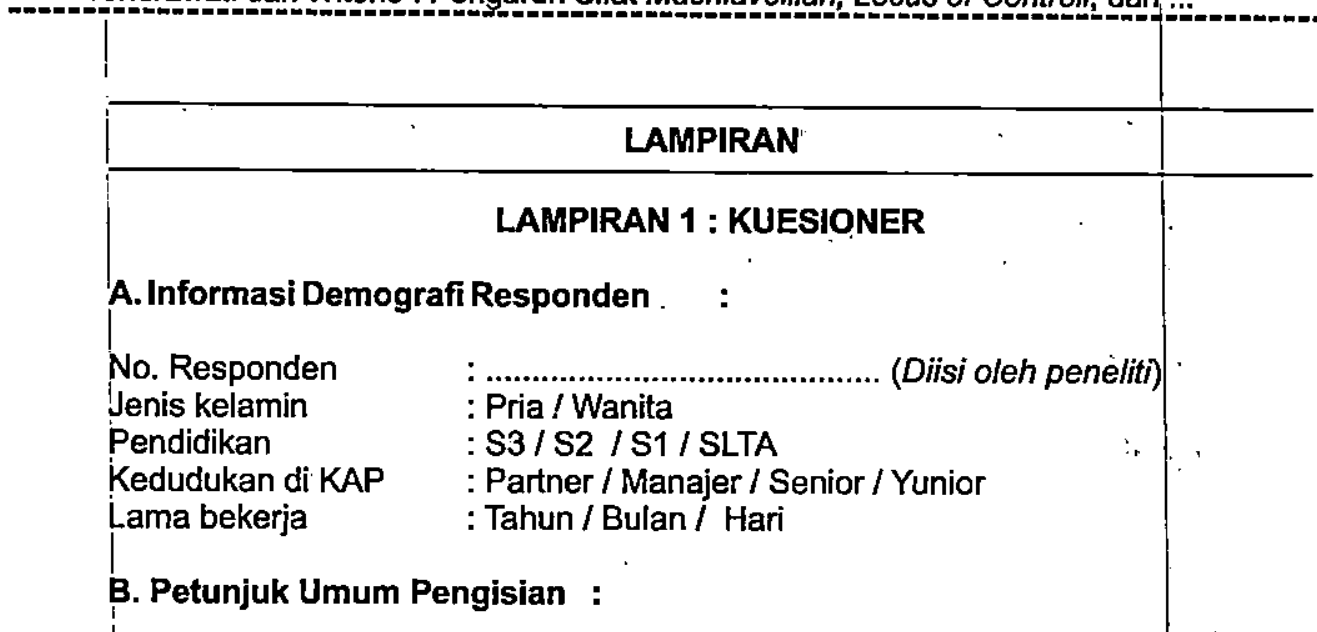

Peryataan-pernyataan berikut berkaitan dengan petunjuk pengisian kuisionerkuisioner yang akan anda isi dibawah ini:

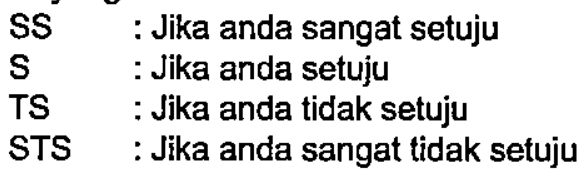

Sifat Machiavellian

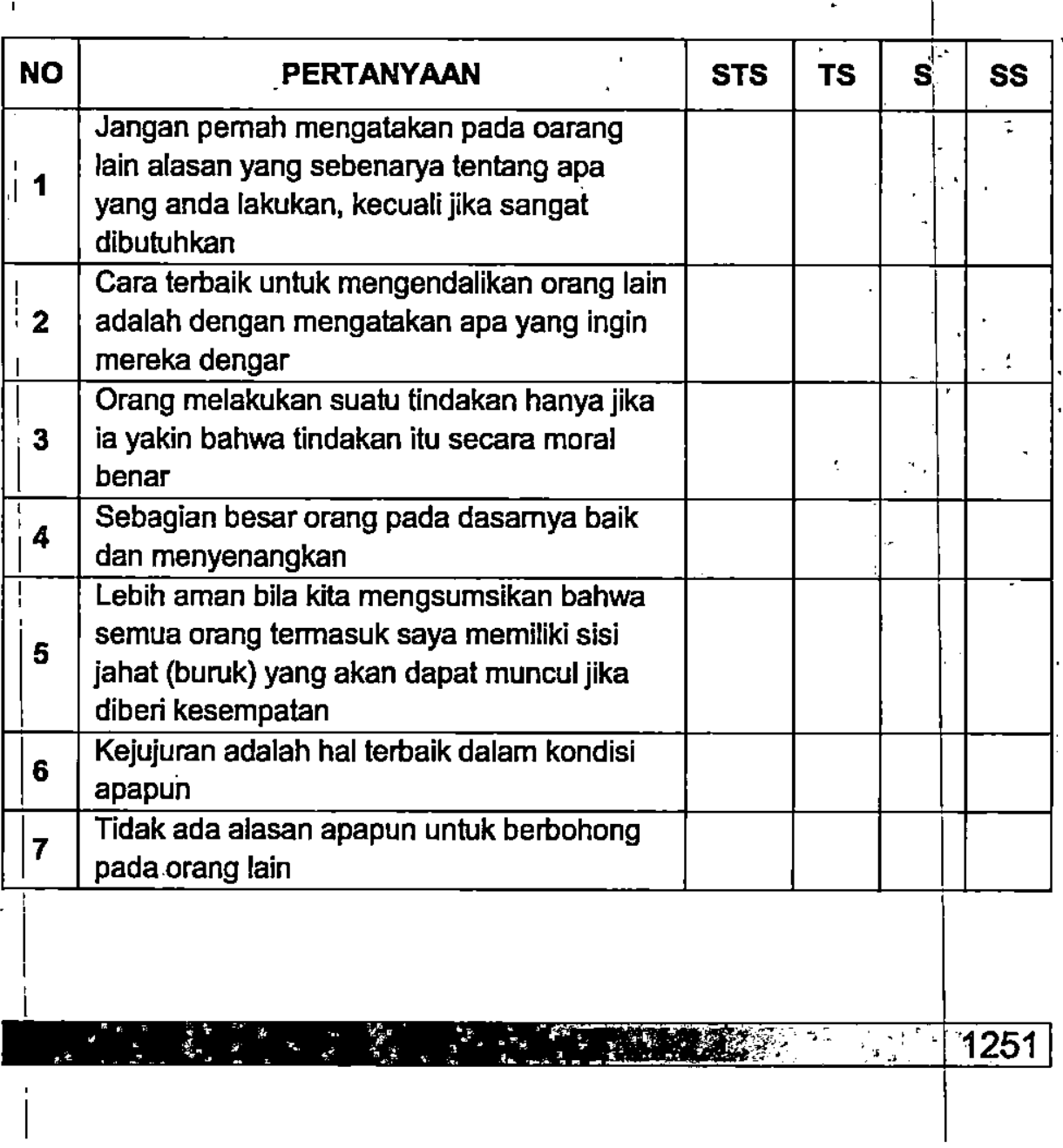




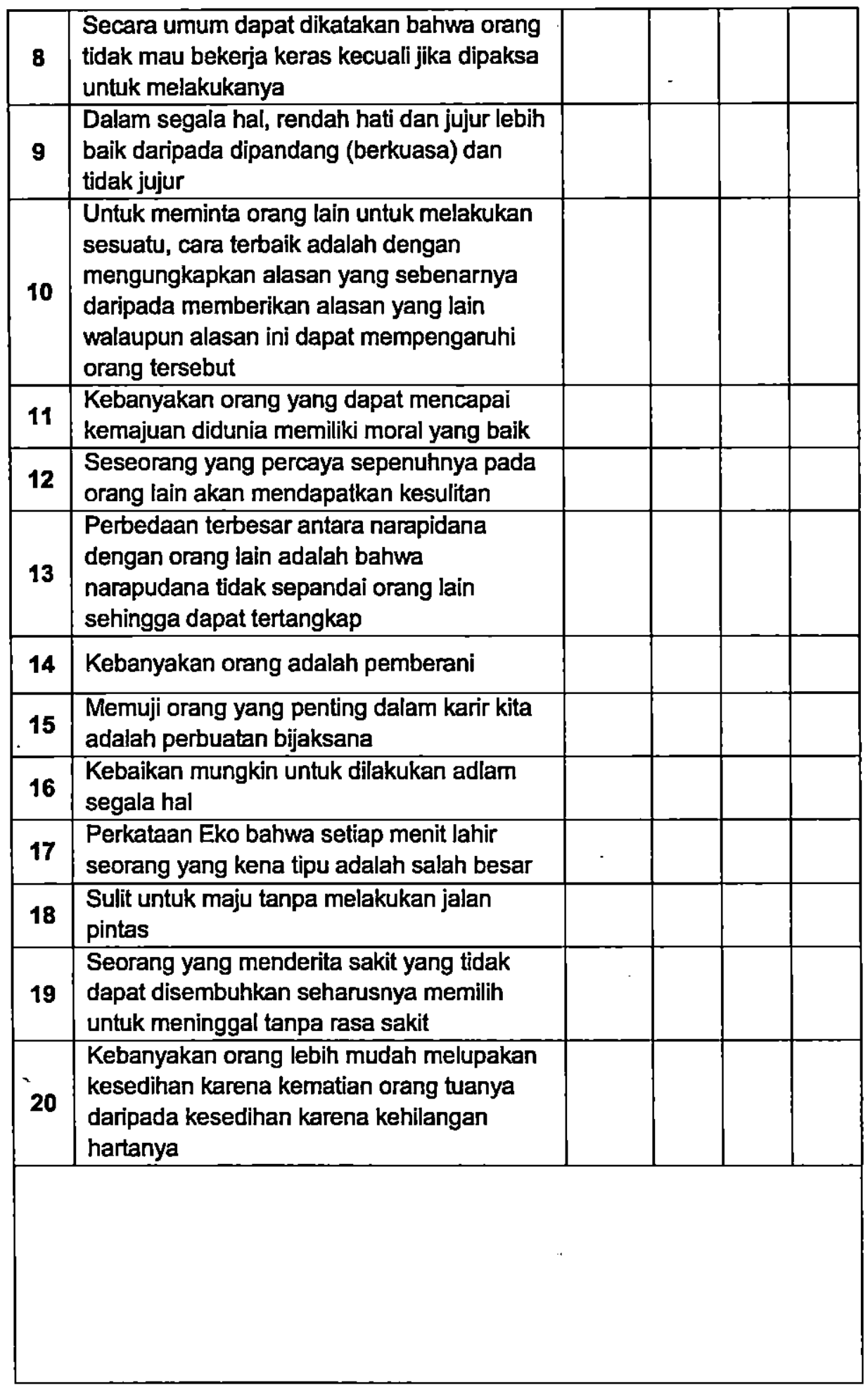




\section{Locus Of Control}

\begin{tabular}{|c|c|c|c|c|c|}
\hline No & PERTANYAAN & STS & TS & $\mathbf{s}$ & SS \\
\hline 1 & $\begin{array}{l}\text { Pada setiap penugasan, anggota tim bisa } \\
\text { mennyelesaikan tugas apapun yang ingin } \\
\text { diselesakan }\end{array}$ & & ? & & \\
\hline 2 & $\begin{array}{l}\text { Jika saya menginginkan suatu penugasan, } \\
\text { maka saya akan mendapatkan tugas } \\
\text { tersebut }\end{array}$ & & & & \\
\hline 3 & $\begin{array}{l}\text { Jika saya tidak menyukai keputusan } \\
\text { pemimpin. Saya akan melaksanakan } \\
\text { keputusan tersebut }\end{array}$ & & & & \\
\hline 4 & $\begin{array}{l}\text { Memperoleh penugasan yang saya inginkan } \\
\text { merupakan suatu keberuntungan }\end{array}$ & & & & \\
\hline 5 & $\begin{array}{l}\text { Menghasilkan banyak uang merupakan } \\
\text { suatu nasib baik }\end{array}$ & & & & \\
\hline 6 & $\begin{array}{l}\text { Saya akan mampu melaksanakan } \\
\text { penugasan dengan baik jika mau berusaha }\end{array}$ & & & & \\
\hline 7 & $\begin{array}{l}\text { Untuk memperoleh penugasan yang benar- } \\
\text { benar baik, saya membutuhkan koneksi } \\
\text { yang mempunyai kedudukan tinggi }\end{array}$ & & & & \\
\hline 8 & Promosi selalu merupakan nasib baik & & & & \\
\hline 9 & $\begin{array}{l}\text { Jika membutuhkan suatu penugasan yang } \\
\text { benar-benar baik, koneksi lebih penting } \\
\text { daripada keahlian }\end{array}$ & & & & \\
\hline 10 & $\begin{array}{l}\text { Promosi akan diberikan apabila saya } \\
\text { melaksanakan penugasan dengan baik }\end{array}$ & & & & \\
\hline |11 & $\begin{array}{l}\text { Untuk menghasilkan banyak uang, saya } \\
\text { harus mengenal orang yang mempunyai } \\
\text { pengaruh }\end{array}$ & & & & \\
\hline 12 & $\begin{array}{l}\text { Orang yang melaksanakan penugasan } \\
\text { dengan baik akan memperoleh penghargaan }\end{array}$ & & & & \\
\hline 13 & $\begin{array}{l}\text { Kebanyakan anggota tim memiliki pengaruh } \\
\text { yang besar terhadap pemimpin lebih } \\
\text { daripada yang mereka kira }\end{array}$ & & & & \\
\hline 14 & $\begin{array}{l}\text { Perbedaan utama antara orang yang } \\
\text { menghasilkan banyak uang dengan orang } \\
\text { yang menghasilkan sedikit uang adalah } \\
\text { keberuntungan }\end{array}$ & & & & \\
\hline
\end{tabular}

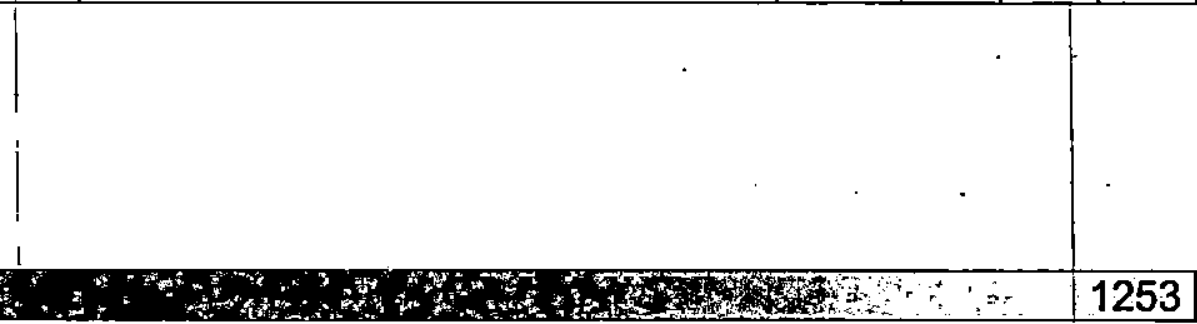


Independensi

\begin{tabular}{|c|c|c|c|c|c|}
\hline No & PERTANYAAN & STS & TS & $\mathbf{S}$ & SS \\
\hline 1 & $\begin{array}{l}\text { Penyusunan progam audit bebas dari } \\
\text { campur tangan pimpinan untuk menentukan, } \\
\text { mengeliminasi atau memodifikasi bagian- } \\
\text { bagian tertentu yang diperiksa }\end{array}$ & & & & \\
\hline 2 & $\begin{array}{l}\text { Penyusunan progam audit bebas dari } \\
\text { campur tangan atau suatu sikap tidak mau } \\
\text { bekerjasama mengenai penerapan prosedur } \\
\text { yang dipilih }\end{array}$ & . & & & \\
\hline 3 & $\begin{array}{l}\text { Penyusunan progam audit bebas dari } \\
\text { usaha-usaha pihak lain terhadap subyek } \\
\text { pekerjaan pemeriksaan selain untuk proses } \\
\text { pemeriksaan yang disediakan }\end{array}$ & & & & \\
\hline 4 & $\begin{array}{l}\text { Pemeriksaan langsung dan bebas } \\
\text { mengakses semua buku-buku, catatan- } \\
\text { catatan, pejabat dan karyawan perusahaan, } \\
\text { serta sumber informasi lain yang } \\
\text { behubungan dengan kegiatan, kwajiban- } \\
\text { kwajiban, dan sumber-sumber bisnis }\end{array}$ & & & & \\
\hline 5 & $\begin{array}{l}\text { Pelaksanaan pemeriksaan aktif bekerjasama } \\
\text { dengan pribadi manajerial selama proses } \\
\text { pemerikasaan akuntan }\end{array}$ & & & & \\
\hline 6 & $\begin{array}{l}\text { Pemerikasaan bebas dari usaha-usaha } \\
\text { manajerial untuk menentukan atau } \\
\text { menunjuk kegiatan yang akan diperiksa atau } \\
\text { untuk menentukan dapat diterimanya } \\
\text { masalah pembuktian }\end{array}$ & & & & \\
\hline 7 & $\begin{array}{l}\text { Pemeriksaan bebas dari kepentingan pribadi } \\
\text { atau hụbungan emosional }\end{array}$ & & & & \\
\hline 8 & $\begin{array}{l}\text { Pelaporan bebas dari perasan kwajiban } \\
\text { untuk memodifikasi pengaruh fakta-fakta } \\
\text { yang dilaporkan pada pihak tertentu }\end{array}$ & & & & \\
\hline 9 & $\begin{array}{l}\text { Pelaporan menghindari praktek untuk } \\
\text { meniadakan persoalan penting dari laporan } \\
\text { formal ke laporan informal bentuk tertentu } \\
\text { yang disenangi }\end{array}$ & & & & \\
\hline 10 & $\begin{array}{l}\text { Pelaporan menghindari bahasa atau istilah- } \\
\text { istilah yang mendua arti secara sengaja atau } \\
\text { tidak dalam pelaporan fakta-fakta, pendapat, } \\
\text { rekomendasi, serta dalam penafsiranya }\end{array}$ & & & & \\
\hline
\end{tabular}




\begin{tabular}{|l|l|l|l|l|l|}
\hline 1 & $\begin{array}{l}\text { Pelaporan bebas dari usaha tertentu untuk } \\
\text { mengesampingkan pertimbangan akuntan } \\
\text { pemeriksa terhadap isi laporan } \\
\text { pemeriksaan, baik fakta maupun } \\
\text { pendapatnya }\end{array}$ &. & $\cdot$ & & \\
\hline
\end{tabular}

\section{Perilaku Etis}

Anda diminta membaca dengan teliti mengenai kejadian dibawah ini, kemudian memilih jawaban dengan melingkari salah satu angka dari 1 (sangat tidak setuju) sampai 5 (sangat setuju) yang tertera dibawah pernyataan.

Anda adalah seorang manajer kredit sebuah bank. Seorang teman dekat anda yang memiliki sebuah perusahaan ban mengajukan pinjaman ke bank tempat anda bekerja. Analisis kkredit tempat anda bekerja menyatakan bahwa perusahaan tersebut tidak memenuhi kriteria normal pinjaman bank. Apakah anda sebagai teman dekat pernilik perusahaan yang mengajukan pinjaman akkan merekomendasikan pinjaman kepadanya?
1.STS
2.TS
4.5
5.SS

Anda adalah seorang menajer pemasaran yang sedang menghadapi kenyataan bahwa target penjualan kuartal kali ini tidak akan terpenuhi, sehingga bonusnya tidak akan anda terima. Sementara itu ada order penjualan yang tanggal permintaan pengiriman barangnya masuk ke perioder kurtal depan. Jika permintaan tersebut dipenuhi sekarang (sébelum tanggalpermintaan pengiriman barang), maka target penjualan akan 'terpenuhi. Apakah anda akan mengirimkan order sebelum waktu yang diminta pelanggan dengan tujuan memperoleh bonus?

\begin{tabular}{|c|c|c|c|c|}
\hline 1.STS & 2.TS & 4.5 & $5.5 S$ & \\
\hline
\end{tabular}

Anda adalah akuntan yang mengelola sebuah kantor akuntan publik|(KAP) dengan seorang partner. KAP anda sedang menghadapi kondisi resesi, 'sehingga diputuskan untuk melakukan perampingan. Analisis produktivitas mengarah pada seorang karyawan lama yang mempunyai banyak catatan absen karena alasan sakit dalam keluarganya. Namun partner anda jurtru merekomendasikan untuk memberhentikan seorang kkaryawan muda yang baru, namun sangat kompeten. Keputusan akhir ada ditangan anda. Apakah 'anda akan mengambil keputusan sesuai dengan rekomendasi partner anda?

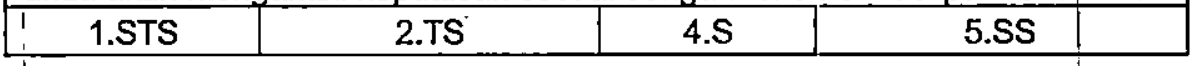

Anda adalah seorangg manajer sebuah perusahaan yang ingin mengembangkan bisnis keluar negeri. Untuk pengembangan bisnis keluar negeri tersebut harus dilakukan sebuah pembayaran 'gelap' kepada seorang 'distribusi lokal disuatu negara asing. Pembayaran itu sebagai 'goodwill 'gesture' agar perusahaan anda dapat memasukan produknya ke negara asing tersebut. Praktik ini normal dalam prosedur bisnis dinegara tersebut dan tidak ada hukum disana yang melarangnya. Apakah anda sebagai manajer perusahaan akan mengotorisasi pembayaran tersebut?

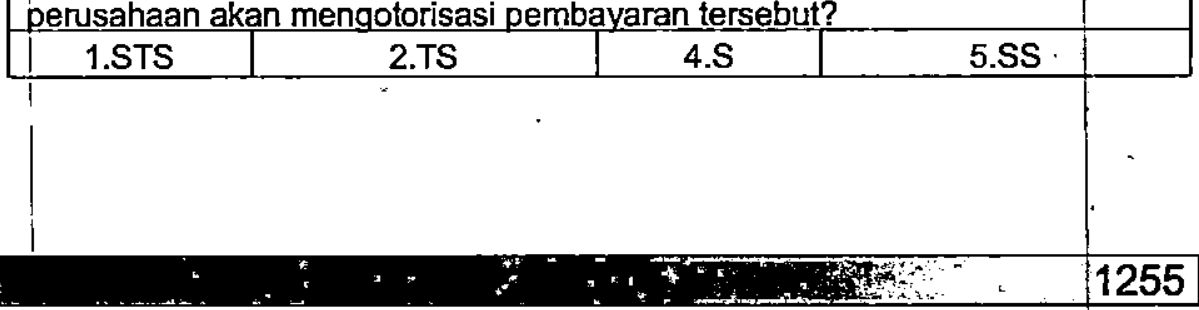


Anda adalah seorang salesman yang baru saja dipromosikan menjadi manajer produksi. Tanggung jawab pertama anda adalah menangani produk baru peralatan kesehatan. Bagian kompensasi yang akan anda peroleh dihitung bersdasarkan jumlah penjualan produk itu. Ketika melakukan review atas produk baru tersebut, anda menemukan bahwa hasil product testing yang dilakukan tidak cukup untuk memenuhi standar aturan yang ditetapkan oleh pemerintah atas keamanan produk. Namun sejauh ini tidak ditemukan indikasi adanya masalah keamanan bagi konsumen setelah menggunakan produk anda. Apakah anda akan mengotorisasi diteruskanya promosi dan penjualan produk baru tersebut?

\section{STS}

\section{TS}

4.S
5.SS

Anda bekejja disebuah perusahaan, saat ini anda menduduki sebuah jabatan yang menuntut anda untuk melakukan perjalanan dinas jauh dari rumah secara rutin. Frekuensi perjalanan dinasnya tinggi dan membuat anda sering meninggalkan keluarga, maka sebagai konsekuensinnya anda mempertimbangkkan untuk membebankan sebagian kecil pengeluaran pribadi anda seperti pembelian oleh-oleh untuk keluarga pada perusahaan. Apakah hal tersebut akan anda lakukan?

\section{STS}

2.TS

4.5

5.SS

Kondisi perusahaan tempat anda bekerja saat ini sedang mengalami penurunan laba pada beberapa periode belakangan ini, maka general manajer perusahaan anda meminta anda untuk menurunkan estimasi piutang tak tertagih untuk meningkatkan laba, dengan argumentasi bahwa praktik ini bisa dilakukan ketika industri sedang dalam kondisi yang tidak baik. Sebelumnya perusahaan sangat konservatif dalam menentukan cadangan kerugian piutang, sekalipun masa-masa yang berat. Permintaan general manajer tersebut menjadikan cadangan kerugian piutang perusahaan yang paling tidak konservatif dibandingkan perusahaan lain dalam industri yang sama. Apakah anda akan mengambil keputusan untuk melakukan penyesuaian terhadap cadangan kerugian piutang perusahaan tersebut untuk meningkatkan laba perusahaan?

1.STS

2.TS

4.S

5.SS

Anda adalah pemilik suatu paket database software yang memliki nilai sangat besar. Saat ini ada rekan anda, pemilik sebuah perusahaan lokal keçil, yang sedang dalam kesulitan keuangan, sedang melakukan pendekatan pada anda agar dijjinkan meminjam dan mengkopi database software yang anda miliki tersebut untuk mengembangkan bisnis dimasa depan. Apakah anda sebagai teman baiknya akan meminjamkan database software tersebut?

1.STS
2.TS
4.S

5.SS 